\title{
SWAT SUBBASINS PARAMETERS AND FLOOD RISK SIMULATIONS USING 3D IN
} TERENGGANU WATERSHED

\author{
Ibrahim Sufiyan ${ }^{1 *}$, Razak Bin Zakariya ${ }^{1^{*}}$, Rosnan Yacoob ${ }^{2 *}$, Md.Suffian Idris ${ }^{2 *}$, Nasir M. Idris ${ }^{3^{*}}$ \\ ${ }^{1}$ School of Marine and Environmental Sciences, Universiti MalaysiaTerengganu, 21030 Kuala Terengganu, Terengganu, Malaysia \\ ${ }^{2}$ School of Marine and Environmental Science. Universiti Malaysia Terengganu \\ ${ }^{3}$ Department of Geography Faculty of Environmental Science, Nasarawa State University, P.M.B 1022 Keffi, Nasarawa State, Nigeria. \\ *Corresponding Author Email: ibrahimsufiyan0@gmail.com, ajak@umt.edu.my,rosnan@umt.edu.my, suffiian@umt.edu.my,medugu@gmail.com
}

This is an open access article distributed under the Creative Commons Attribution License, which permits unrestricted use, distribution, and reproduction in any medium, provided the original work is properly cited

\section{ARTICLE DETAILS}

Article History:

Received 12 November 2017 Accepted 12 December 2017 Available online 1 January 2018

\section{ABSTRACT}

Flood is one of the natural disasters that occurs mostly due to climate characteristics and locations. The application of SWAT has categorized the subbasins and identify them on the basis of parameters. The use of GIS technology produces the flood risk zone through the 3D ArcScene 10.3. the ArcGIS 10.3 and ArcSWAT 2012 were employed for the analysis of the result. The remote sensing data from ASTER DEM was also been used for providing the highresolution platform. One of the significance of this study is the identification of 25 different sub-basins with their individual parameters that make easiear to classify and explore. The 3Dsimulation produces different categories of flood risk zone from very high vulnerability of flood to no flood risk zone. All these are confined within the 25 subbasins parameters obtained from the catchment area of Terengganu. The model designed in this study is clearly going to be useful for planning as well as management not only in Terengganu but entire Malaysia or similar environment.

\section{KEYWORDS}

Flood risk, Subbasins, 3D simulation, SWAT, GIS .

\section{INTRODUCTION}

Magnetic Flood events are a part of nature. They have existed and will continue to exist. As far as feasible, human interference into the processes of nature should be reversed, compensated and, in the future, prevented. According to research stated that annually flooding causes more property damage in the United States than any other type of natural disaster Considering the evolution and trends, the approach to natural hazards requires a change of paradigm. One must shift from defensive action against hazards to management of the risk and lives with floods, bearing in mind that flood prevention should not be limited to flood events which occur often [1]. It should also include rare events. Web-based hydrological modeling system permits integrated handling of real-time rainfall data from a wireless monitoring network. A spatially distributed GIS-based model is integrated on the basis of this incoming data, approximating realtime to produce data on catchment hydrology and runoff. A group researchers emphasizes that flood forecasting and a warning is a prerequisite for successful mitigation of flood damages [2]. Its effectiveness depends on the level of preparedness and correct response. Therefore the responsible authorities should provide timely and reliable flood warning, flood forecasting and information. The Terengganu river catchment is flooding during the monsoon season. It proximity to South China Sea has contributed coupled with high evapotraspiration and humidity.

The wave action almost erodes the coastal region and tha course concern. One of the problem is improper drainage if at all available but very narrow to accomodate large volume of water from the sub-basins. Different functions of GIS tools to provide more accurate measures of flood risks [1]. Water is supplied to rivers from precipitation in the drainage basin (catchment area). Some of the precipitation is returned to the atmosphere by evaporation and evapotranspiration, but the remaining stream flow can move down the slope due to the force of gravity to the surface or through ground due to the slope toward rivers. Overland flows are commonly subdivided into infiltration- excess overland flows (due to precipitation rate exceeding infiltration). The relevant coarse weathered material tends to be most common in cold climate and steep slope. Clay (produced by chemical weathering) is numerous in humid climates. The organic material or content made its maximum contribution to the sediment supply in a moist environment [3].

The rate of mass wasting (downslope movement) of loosed materials under the influence of gravity) depends on the composition and texture of the loose materials, the water contains availability, the presence of vegetation, slope angle and ground motion associated with the earthquake. The concentration of dissolved material decreases as water discharge increases, because of the decreasing quantities of groundwater flow. However, the sum of suspended load or sediment increases with discharge.

If there is $\mathrm{N}$ year of record, and the maximum annual discharge are ranked, the most substantial having rank $\mathrm{m}-1$ and the smallest having rank $\mathrm{m}=\mathrm{N}$, then the probability of an annual flood of magnitude $m$ is express as:

$$
\mathrm{P}(\mathrm{x})=\mathrm{m} /(\mathrm{N}-1)
$$

The mean return period of the flood event is

$$
\mathrm{T}=1 / \mathrm{P}(\mathrm{x})
$$

And the cumulative probability is

$$
f(x)=1-P(x)
$$

Frequency distribution of extreme event such as the annual maximum discharge of a river is normally positively skewed. River flow data are fundamentally essential in the management of water resources. Hydrometric data are required for river management and assessment. A specific preparedness to alert, rescue and safety measures should be planned and implemented at all levels, including the public, by maintaining regular basic information and continuous ongoing training actions. The appropriate and timely information, preparedness, everyone who may 
suffer the consequences of flood events should be able to take if possiblehis/her own precautions and thus seriously limit flood damages. Three methods of GIS have relevance; raster data, Triangulated irregular network and contour based line network [4]. Flooding has many impacts. It damages property and endangers the lives of humans and other species. Rapid water runoff causes soil erosion and concomitant sediment deposition elsewhere (such as further downstream or around the coast). The flood risk increases where risk is defined as the probability of occurrence multiplied by its impact. The probability of flooding is expected to increase: the earth's climate is changing rapidly. Since the warm period in the Middle Ages and after the Minor Boulder, the earth is undeniably growing warmer again. Scientists reached agreement on this point at a conference in Shanghai in early 2001. According to a study, based on remote sensing technology, the GIS grid model generated by digital elevation model (DEM) is utilized to analyze the flood submergence [5]. By means of this method, the flooding situation including the extent of flood submergence and water depth distribution is attained. A nationally integrated system using remote sensing, geographic information systems, the Global Positioning System, and other technology for monitoring and evaluating flood disasters can be employed. The system has played an important role in flood mitigation during the trial and has become a key part of the flood management system [6]. Flood damage depends on the hydraulic factors which include characteristics of the flood such as the depth of flooding, the rate of the rise in water level, propagation of a flood wave duration and frequency of flooding, sediment load, and timing [7].

SWAT model is a continuous, long- time distribution of imputed parameters as a model. The uses of the SWAT helps in the simulation of the surface water flow, soil erosion, sediment deposition and nutrient movement in the watershed [8]. The products of SWAT output from the hydrologic response units (HRU) such as the subbasin parameters developed from the catchment was integrated with 3D simulation in the ArcScene environment to produce flood risk models. floods are climatologic phenomena is influenced by the geology, relief, soil, geomorphology and vegetation conditions [9]. There is need to monitor the activities of the flood by applying the modern technology of Geographic Information System [10]. The system will assist in mitigation and controlling flood. The issue of flood disaster is a global phenomenon that requires attention in other to control life and properties. Flood inundation can be detected from remotely sensed data [11]. Flood hazard models are a useful tool for planning the urban city and layout designs [12-14]. Geographic information system (GIS) and remote sensing (RS) techniques have significantly contribute in natural hazard analysis [1518].

\section{MATERIALS AND METHODS}

A complete account of flood model is provided by [19]. In this study, the flood zoning was done in ArcScene compatible to ArcGIS 10.3. the other variable materials were obtained from the Drainage and Irrigation Department (DID) in Malaysia. The data used are the georeferenced map of the study area. Aster DEM satellite image with a resolution of 30 meters was obtained from ASTER DEM, land use/ cover, and soil from the digitized map of Terengganu catchment area.

\section{1 mData Aquisation}

the figure 1 below illustrats how the data of this study were acquired and also demostrates the flow on how the data was used at difference stages in this study.

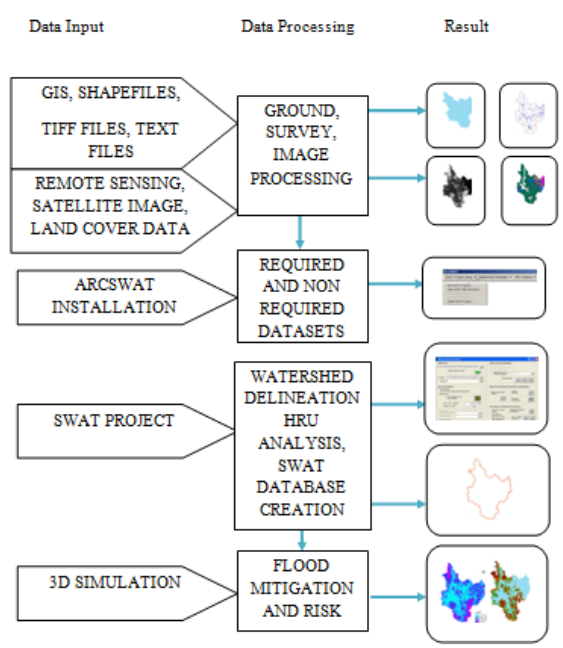

This study is conducted based on the flowchart in figure 2 below. The ArcGIS 10.3 software is used for both the ArcSWAT 2012 and the ArcScene 10.3. The intermittent results obtained from hydrologic response units HRUs in SWAT was overlaid with the 3D simulation model to observe the scenario of those subbasins that are within or outside the very high flood risk zone or very low flood risk zones [20].

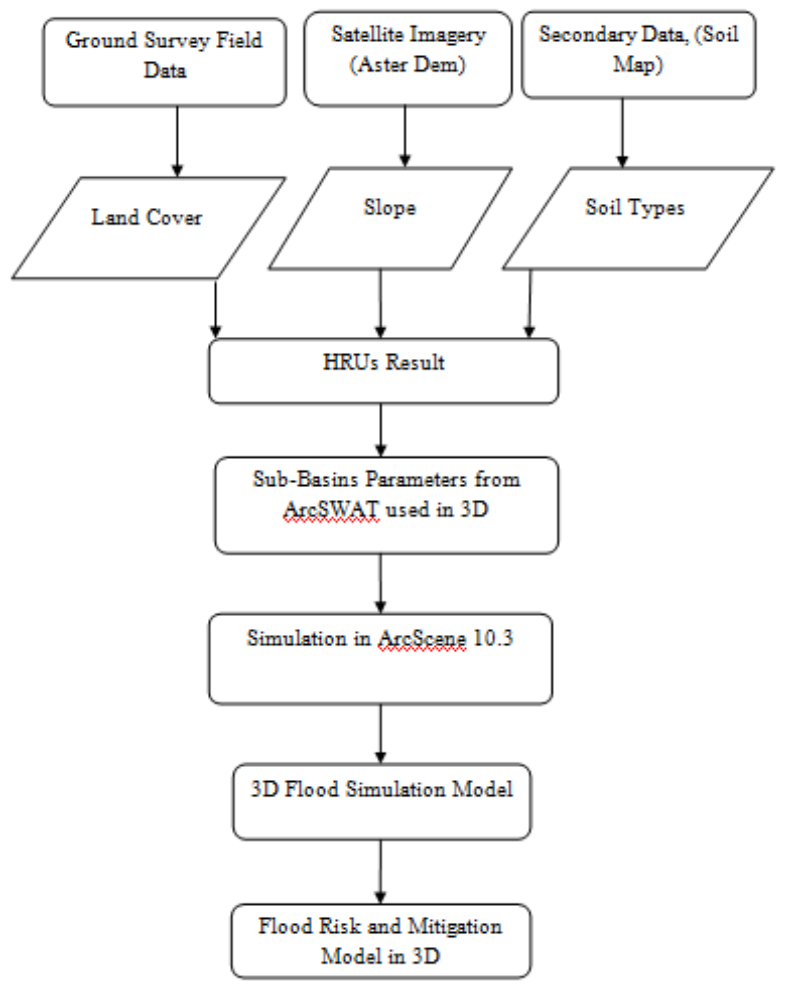

Figure 2: Flow chart

\subsection{Study Area}

The study area that is Terengganu has been experiencing flash flood particularly during the monsoon period of strong rain-bearing wind. In this study, the effort was made to address the issues of flood impact base on the digital image processing and high multispectral resolution of satellite imagery and GIS 3D environment. It is located at upper left corner $50305.407 \mathrm{~N}, 10202315.536 \mathrm{E}$ and the lower right corner is $403924.251 \mathrm{~N}$, $1030116.211 \mathrm{E}$ respectively. The Kuala Terengganu has different district divided base on the communal settlement (Kampung) but the main area of focus is the Kuala Terengganu popularly called the Kuala Nerus [21].

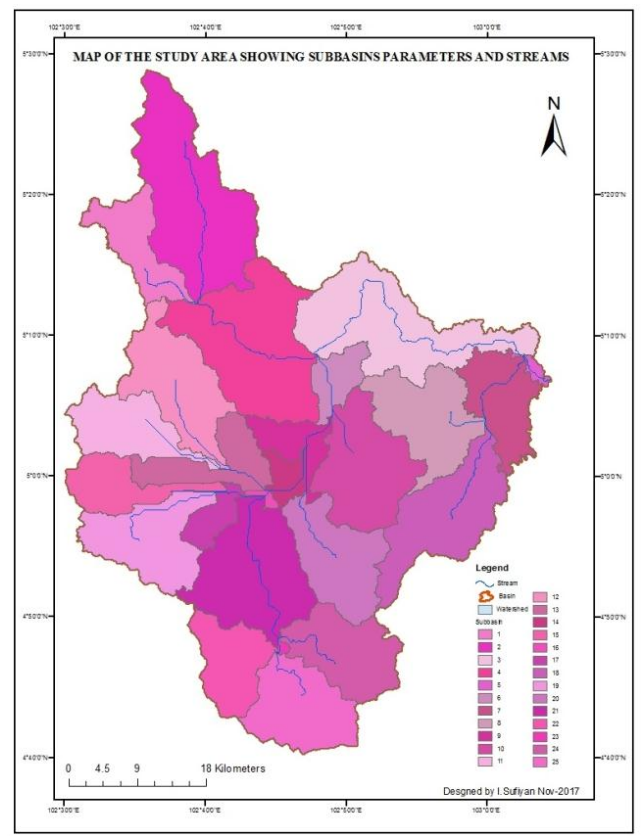




\section{RESULTS}

The recent technology of remote sensing and geographic information system (GIS) has capabilities of locating, mitigating, managing and analyzing areas vulnerable to flood hazard event.

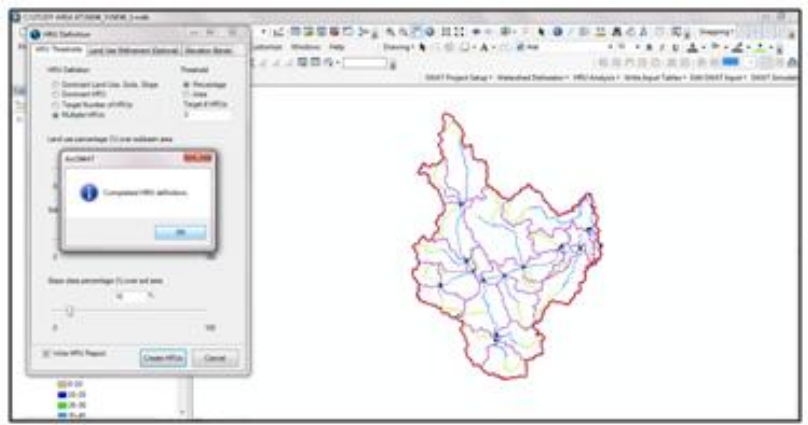

Figure 4: the Delineated watershed of Terengganu River (SWAT output) In this study. About 7 out of 25 subbasins parameters were simulated and are vulnerable to flood hazard and risk as shown in figure 7 . There are about 25 different sub-basins in the study area created by the SWAT. Each of the sub-basins was characterized by a distinct parameter for easy classification and hydrologic analyses. Figure 5 shows the classified subbasins in Terengganu River catchment.

Table 1: The Sumarry and SWAT output

\begin{tabular}{|c|l|c|c|}
\hline $\begin{array}{l}\text { Watershed Number } \\
\text { of Sub-basins: }\end{array}$ & Area [ha] & Area[acres] & Number of HRU's \\
\hline 25 & $286,507.3500$ & $707,973.9872$ & 305 \\
\hline
\end{tabular}

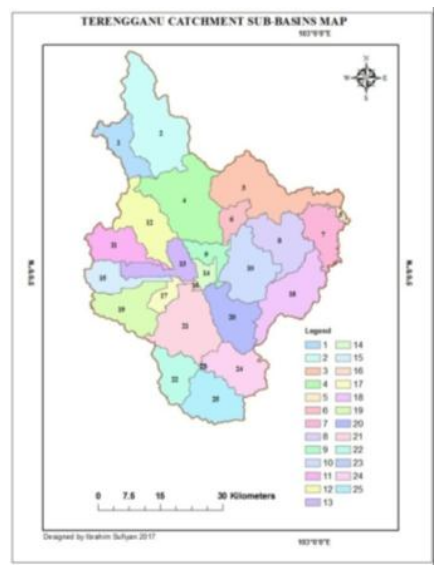

Figure 5: 25 Subbasins Parameters of Terengganu catchment

The major streams in Terengganu as shown in figure 6 are connected by the stream links to the watershed and appended to the whole catchment. The 25 individual sub-basins was defined by the water input and the characteristics of all the hydrologic response units (HRUs) with summary results from SWAT in table 1.

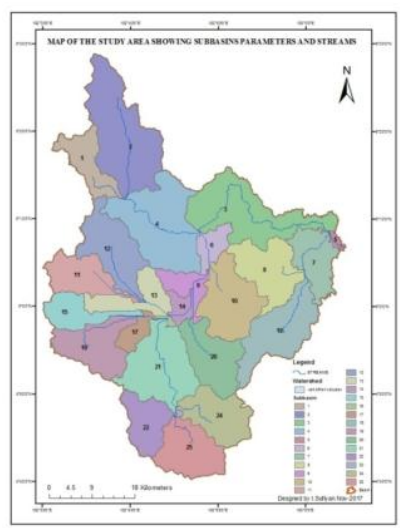

Figure 6: The streams in the subbasins parameters

\subsection{SWAT Watershed Delineation Result}

Watershed is also known as a basin or catchment, or simply an area delineated with a specified outlet point that emptied in a large body of water. The figure below represents the delineated watershed of Kuala Terengganu Catchment. The boundary with brown color in figure 7 is the demarcation of the delineated watershed of the study area. The blue color is the main Rivers that flow toward the South China Sea. The green color is the minor streams in the sub-basins.

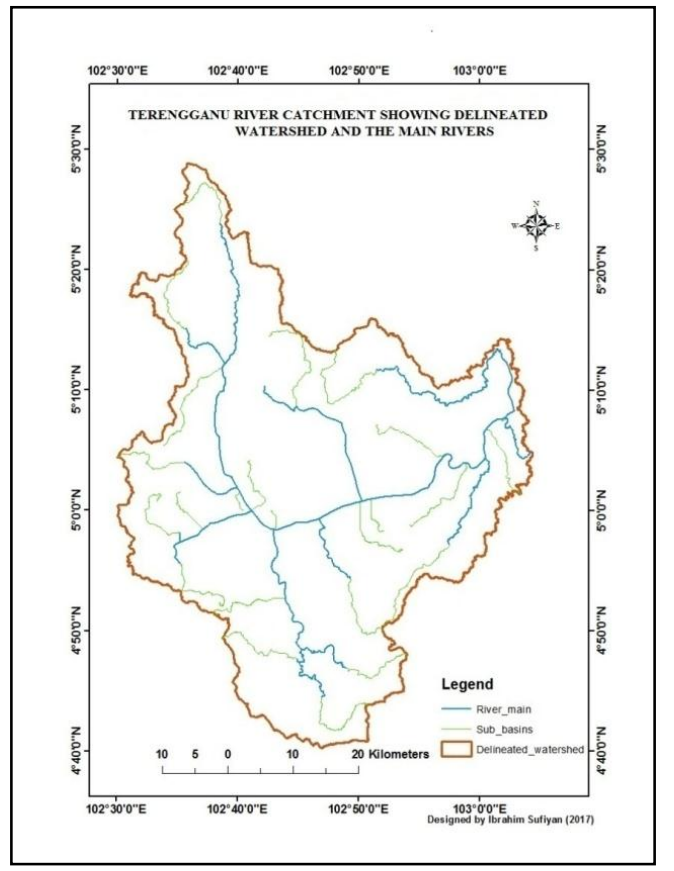

Figure 7: Delineation of the watershed and the main Rivers of Terengganu catchment

\subsection{Stream Network and Reservoirs}

The stream links are developed through the stream network. 10 stream links are obtained from the Terengganu catchment. Each stream link had been connected with the defined sub-basin. The 3 major reservoirs were identified within the watershed as shown in figure 8.

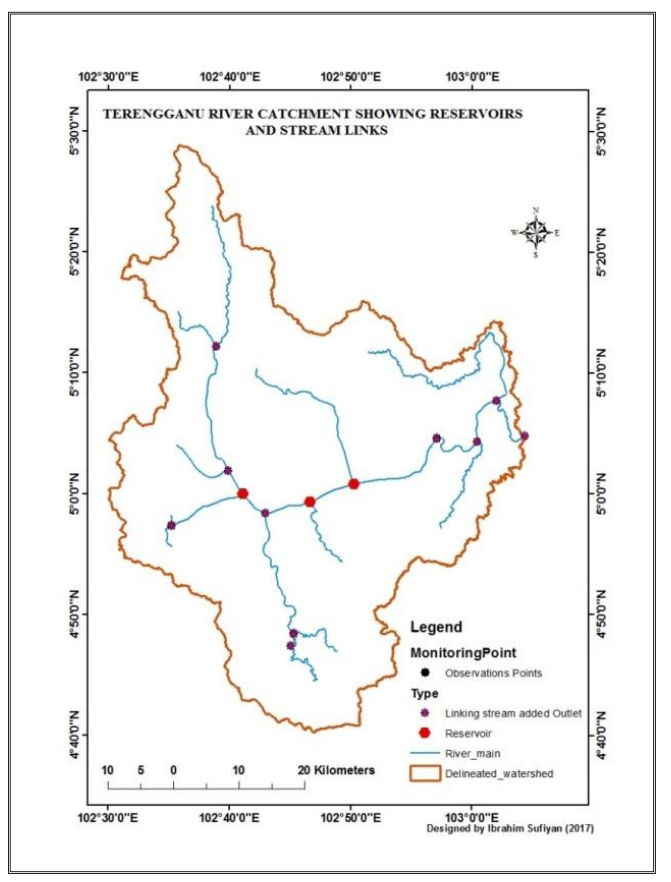

Figure 8: Stream Links and Reservoirs

The Table 2 and 3 present the summary result of the two unique subbasins from the Terengganu river catchment 


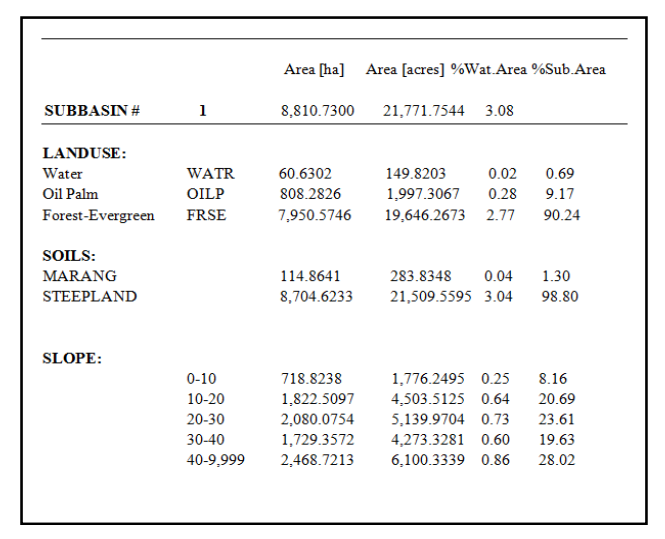

Table 3: The Summary result of subbasin two

\begin{tabular}{|llllll|}
\hline \multicolumn{7}{c|}{ Area [ha] } & Area [acres] \%Wat.Area \%Sub.Area \\
& & \multicolumn{5}{c|}{} \\
SUBBASIN \# & $\mathbf{2}$ & $27,019.5300$ & $66,766.6096$ & 9.43 & \\
\hline LANDUSE: & & & & & \\
Water & WATR & 164.1430 & 405.6055 & 0.06 & 0.61 \\
Oil Palm & OILP & 3.1531 & 7.7915 & 0.00 & 0.01 \\
Forest-Evergreen & FRSE & $26,878.9097$ & $66,419.1297$ & 9.38 & 99.48 \\
& & & & & \\
SOILS: & & & & & \\
MARANG & & $3,939.7921$ & $9,735.4231$ & 1.38 & 14.58 \\
STEEPLAND & & $23,106.4137$ & $57,097.1036$ & 8.06 & 85.52 \\
& & & & & \\
SLOPE: & & & & & \\
& $0-10$ & $2,347.6411$ & $5,801.1386$ & 0.82 & 8.69 \\
& $10-20$ & $5,411.6736$ & $13,372.5160$ & 1.89 & 20.03 \\
& $20-30$ & $5,918.3367$ & $14,624.5058$ & 2.07 & 21.90 \\
& $30-40$ & $5,157.8916$ & $12,745.4080$ & 1.80 & 19.09 \\
& $40-9,999$ & $8,210.6629$ & $20,288.9584$ & 2.87 & 30.39 \\
\hline
\end{tabular}

3D Flood Model developed from the digital elevation model (DEM) of the study area was overlaid with the mask and the Terengganu river flow was considered as a base height. The figure 9 displays the 3D model developed from the ArcScene. At this point, the $\mathrm{Z}$ values are calculated in other to create the simulation. The real-time simulation is presented in the same model. While the simulation was displayed, the purpose is to create a quick alert or warning through animation video perhaps all the areas prone to flooding will be easily identified and mitigation action can be applied.

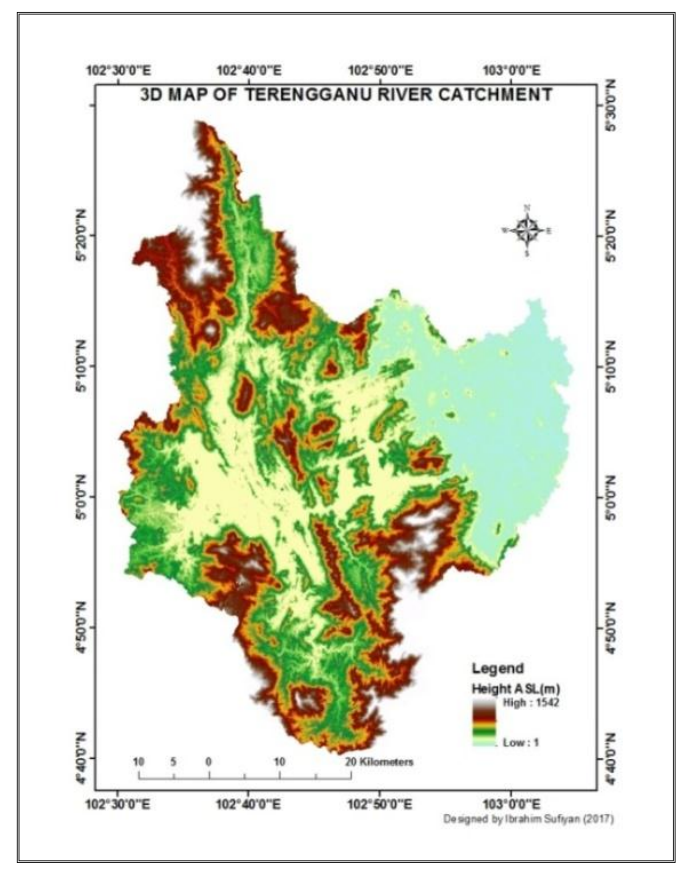

Figure 9: 3D Model of Flood Event of Terengganu River Catchment

The 3D view visualizes the digital elevation model exposing height of the Terengganu River catchment. The streams within this catchment enter into the subbasins. The DEM was set on floating layer above 3.5 meters and the mask of the water level is on 3 meters.the $\mathrm{Z}$ translation values are from $0-100,200,300$ to the required $Z$ values as seen in figure $5 a, b$. The results of flood risk model predicted that the Terengganu catchment has the lowest flood from 3 meters level to the highest 5 meters in the realtime simulation models as shown in figure $10 \mathrm{a}, \mathrm{b}$.
$3 \mathrm{Da}$

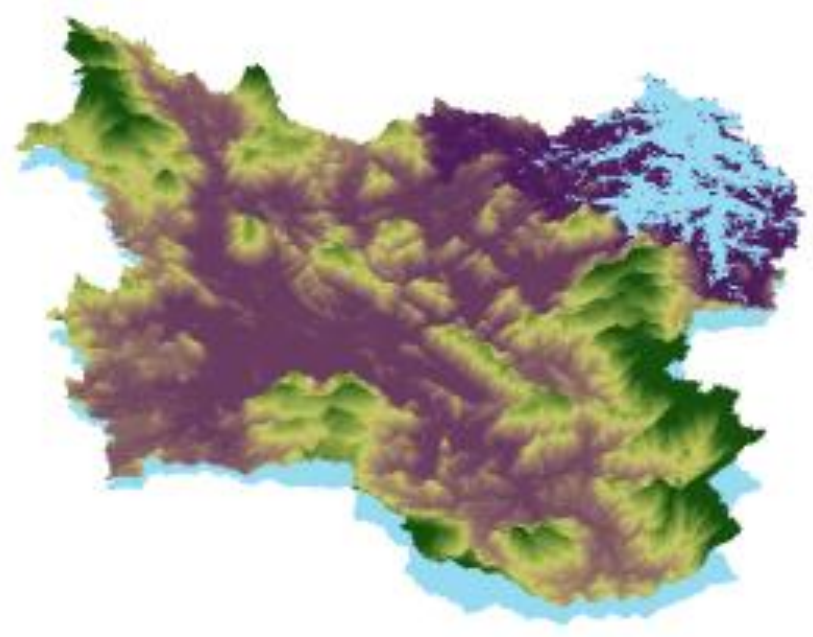

$3 \mathrm{Db}$

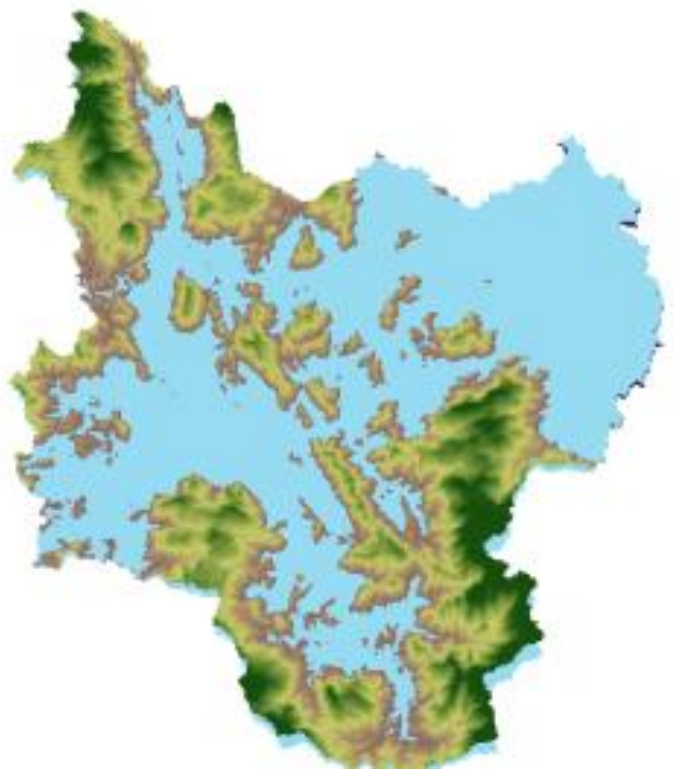

Figure 10: 3Da,b predicted flood simulation model of Terengganu catchment

Flood Risk and Mitigation Model of Terengganu River catchment were developed The flood risk model was shown in figure 11 below. The yardstick is to measure the magnitude of the flood risk in the catchment. Here we arrived at the categories of flood risk from the highest risk to moderate and to no risk zones within the watershed. The flood risk model represents the risk zones which can be used for mitigation, planning, and a warning to the public. From the model below the survey conducted and shows that people despite the warning given to them still occupying residence near the river banks which are at very high flood risk in Terengganu, followed by those on the flatlands from 1 to 2 meters which are on high flood risk. 


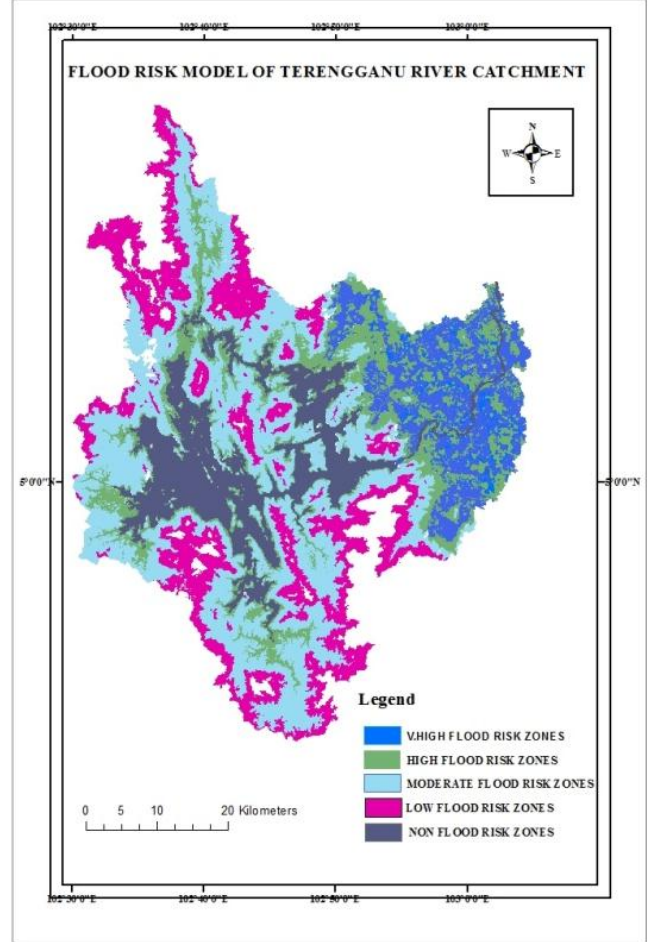

Figure 11: High and Low Flood Risk Model of Terengganu catchment

Flood risk can be evaluated using weightage criterion index can also be adapted base on the flood risk assessment model.

$\operatorname{Risk}_{i}=\sum_{i=1}^{n}$ Wi li $(x, y)$

$=w_{1} l_{1}(x, y)+w_{2} l_{2}(x, y)+w_{3} l_{3}(x, y)+w_{4} l_{4}(x, y)+w_{5} l_{5}(x, y)+w_{6} l_{6}(x, y)+w_{7} l_{7}(x, y)$ $+w_{8} l_{8}(x, y)+w_{9} l_{9}(x, y)$

Where wi can be the weight $\operatorname{li}(\mathrm{x}, \mathrm{y})$ as criterion index, $\mathrm{x}, \mathrm{y}$ as the geographical coordinate and the other sequences can be the remaining variables such as the slope, elevation, density, flow depending on the site selection and the input data of the study area is waa also applied to field of hydrolog $[22,23]$.

The flood risk assessment was shown in figure 12. Each of the 25 subbasins parameters have a different magnitude of flood risk developed from both the ArcSWAT hydrologic response units HRUs and the 3D simulation model. Basically, the simulation shows which zone within each subbasin is severely affected by flood in the 25 subbasins of the study area.

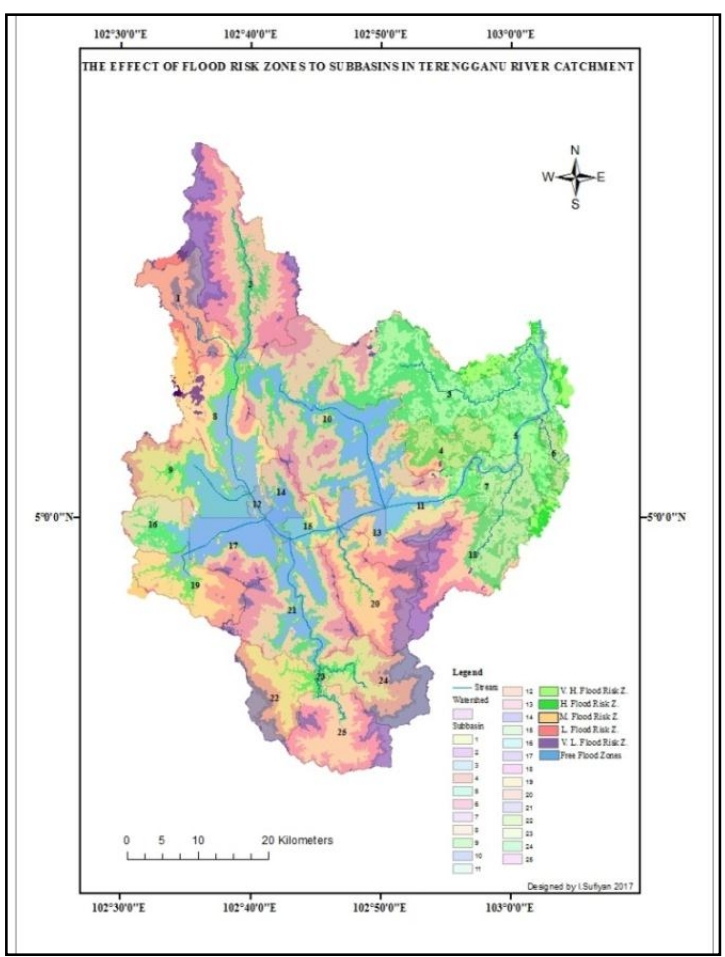

Figure 12: Individual subbasins flood risk analysis
FLOOD OCCURRENCE

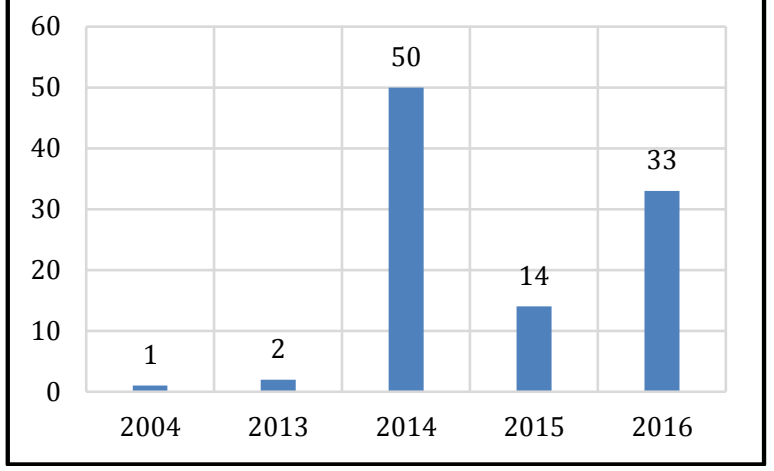

Figure 13: Highest year of flood occurrences in Terengganu

Figure 13 demonstrates the years of flood occurrences in Terengganu. The year 2014 has 50\%, 2016 with 33\%, 2015 has $14 \%$ and rest of the years has had very low flood events. While figure 14 shows the bar graph with a maximum point of flood occurrence.

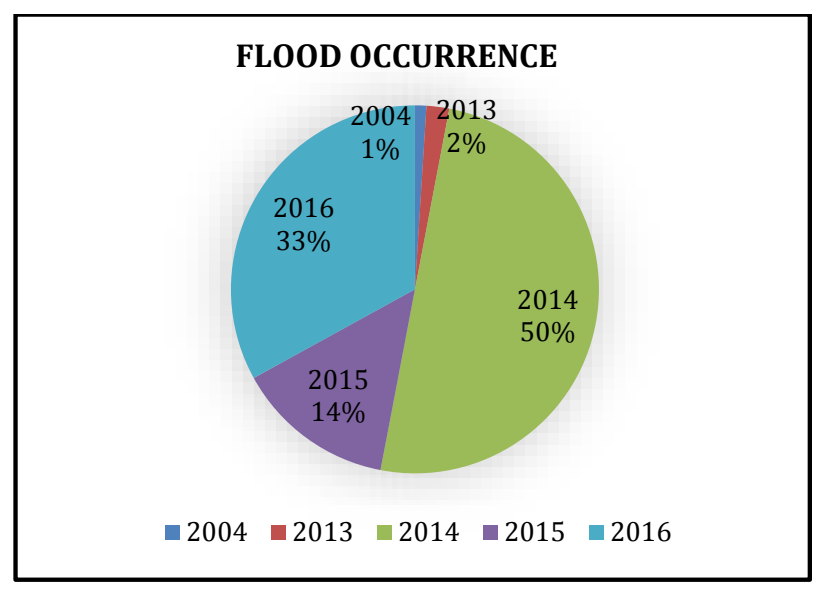

Figure 14: Percentages of years of flood occurrence Terengganu

The expected heavy rainfall in Terengganu is during months November and December. During this period, monsoon rain commences and the flood is experienced. This occurs in most parts of Peninsular Malaysia. Figure 15 clearly illustrates the highest month of rainfall in the study area. Base on this information, we are expected to have been prepared for the flood occurrence.

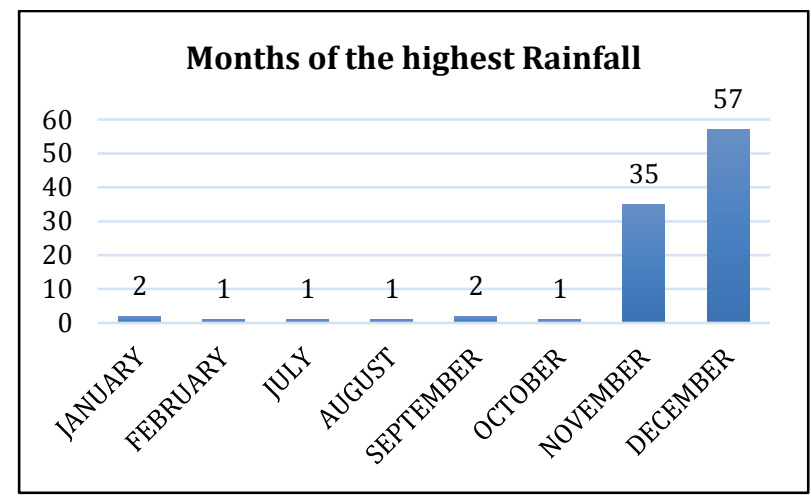

Figure 15: The Two Highest Months of Rainfall

\section{DISCUSSION}

The model outputs will be used to demarcate areas liable to flood and help in notifying people about predicted simulation of flood hazard Although floods are natural phenomena, human activities and human interventions has been affecting the processes of nature such as alterations in the drainage patterns, urbanization, agricultural practices, and deforestation have considerably changed the situation in whole river basins. In the same time, exposition to risk and vulnerability in flood-prone areas have been growing constantly. Flood events are part of nature; they have always existed and will continue to exist. The flood risk assessment was shown in figure 11. Each of the 25 subbasins parameters have a different magnitude of flood risk developed from both the ArcSWAT HRU and the 3D simulated 
model basically to appended to it and show which zone within each subbasin is severely affected by the flood. The 25 subbasins in the study area follow the slope magnitude of the DEM. for mitigation action, we can select and predicts which subbasins in the catchment are highly suitable and liable to flood at each point in time, depending on the intensity and duration of the rainfall. The simulation predicted subbasins that are affected by the flood. This is subbasin number $3,5,6,7,8,10$, and 18

\section{CONCLUSION}

There are many ways of reducing flood risk and hazard event.The result showed that flood usually affects flat land. Therefore, proper drainage system, reforestation, proper waste disposal system and public media enlightenment will be part of the solutions. People living around the affected subbasins should take note of the flood magnitude at regular interval. The flood warning and alert, shelter and safety are one of the mitigations required within each individual subbasin in Terengganu catchment. The flood risk models of Terengganu River catchment was simulated showing flood risk zoning of individual subbasins which can be used for mitigation and planning of flood control. The SWAT output of Hydrologic Response Units (HRUs) was obtained as the first objective. The 3 crucial SWAT input data of land covers, local soils and slopes were calculated base on the percentages each is representing the catchment.

The second objective is to determine the sub-basins parameters that are susceptible to flood risk in the catchment area of Terengganu. The human interference of the human development through urbanization, construction and modern agricultural has affected the sustainability of the physical environment in Terengganu. The removal of some portions of significant land covers in the Terengganu River catchment and dumping of deposited materials as affected the drainage and blockage of waterways that contributed to flooding.

\section{ACKNOWLEDGMENT}

the research was conducted in the faculty of Marine and Environmental Science, Universiti Malaysia Terengganu under the supervision of Dr. Razak BiN Zakariya, Department of Remote Sensing and GIS.

\section{REFERENCES}

[1] Bartosova, A., Clark, D.E., Novotny, V., Taylor, K.S. 2000. Using GIS to evaluate the effects of flood risk on residential property values.

[2] Al-Sabhan, W., Mulligan, M., Blackburn, G. A. 2003. A real-time hydrological model for flood prediction using GIS and the WWW. Computers, Environment and Urban Systems, 27 (1), 9-32.

[3] Leopold, L.B., Wolman, M.G., Miller, J.P. 2012. Fluvial processes in geomorphology. Courier Corporation.

[4] DeVantier, B.A., Feldman, A.D. 1993. Review of GIS applications in hydrologic modeling. Journal of Water Resources Planning and Management, 119 (2), 246-261.

[5] Ding, X.L., Liu, G.X., Li, Z.W., Li, Z.L., Chen, Y.Q. 2004. Ground subsidence monitoring in Hong Kong with satellite SAR interferometry. Photogrammetric Engineering \& Remote Sensing, 70 (10), 1151-1156.

[6] Zhang, J., Zhou, C., Xu, K., Watanabe, M. 2002. Flood disaster monitoring and evaluation in China. Global Environmental Change Part B: Environmental Hazards, 4 (2), 33-43.

[7] Islam, M., Sado, K. 2000. Flood hazard assessment in Bangladesh using NOAA AVHRR data with geographical information system. Hydrological Processes, 14 (3), 605-620.

[8] Arnold, J.G., Srinivasan, R., Muttiah, R.S., Williams, J.R. 1998. Large area hydrologic modeling and assessment part I: Model development1. Wiley Online Library.

[9] Lau, C.L., Smythe, L.D., Craig, S.B., Weinstein, P. 2010. Climate change, flooding, urbanisation and leptospirosis: fuelling the fire. Transactions of the Royal Society of Tropical Medicine and Hygiene, 104 (10), 631-638.

[10] Chan, N.W. 2015. Impacts of disasters and disaster risk management in malaysia: The case of floods. In Resilience and Recovery in Asian Disasters, 239-265. Springer.

[11] Lin, H., Chen, M., Lu, G., Zhu, Q., Gong, J., You, X., Hu, M. 2013. Virtual geographic environments (VGEs): a new generation of geographic analysis tool. Earth-Science Reviews, 126, 74-84.

[12] Tehrany, M.S., Pradhan, B., Jebur, M.N. 2014. Flood susceptibility mapping using a novel ensemble weights-of-evidence and support vector machine models in GIS. Journal of Hydrology, 512, 332-343.

[13] Büchele, B., Kreibich, H., Kron, A., Thieken, A., Ihringer, J., Oberle, P., Nestmann, F. 2006. Flood-risk mapping: contributions towards an enhanced assessment of extreme events and associated risks. Natural Hazards and Earth System Sciences, 6 (4), 485-503.

[14] Rahmati, O., Samani, A.N., Mahdavi, M., Pourghasemi, H.R., Zeinivand, H. 2015. Groundwater potential mapping at Kurdistan region of Iran using analytic hierarchy process and GIS. Arabian Journal of Geosciences, 8 (9), 7059-7071.

[15] Patel, D.P., Srivastava, P.K. 2013. Flood hazards mitigation analysis using remote sensing and GIS: correspondence with town planning scheme. Water Resources Management, 27 (7), 2353-2368.

[16] Pourghasemi, H.R., Jirandeh, A.G., Pradhan, B., Xu, C., Gokceoglu, C. 2013. Landslide susceptibility mapping using support vector machine and GIS at the Golestan Province, Iran. Journal of Earth System Science, 122 (2), 349-369.

[17] Jaafari, A., Najafi, A., Pourghasemi, H. R., Rezaeian, J., Sattarian, A. 2014. GIS-based frequency ratio and index of entropy models for landslide susceptibility assessment in the Caspian forest, northern Iran. International Journal of Environmental Science and Technology, 11 (4), 909-926.

[18] Pradhan, B., Shafiee, M., Pirasteh, S. 2009. Maximum flood prone area mapping using RADARSAT images and GIS: Kelantan river basin. International Journal of Geoinformatics, 5 (2), 11.

[19] Bates, P.D., De Roo, A.P.J. 2000. A simple raster-based model for flood inundation simulation. Journal of Hydrology, 236 (1), 54-77.

[20] Di Baldassarre, G., Schumann, G., Bates, P. 2009. Near real time satellite imagery to support and verify timely flood modelling. Hydrological Processes, 23 (5), 799-803.

[21] Marghany, M., Ibrahim, Z., Van Genderen, J. 2002. Azimuth cut-off model for significant wave height investigation along coastal water of Kuala Terengganu, Malaysia. International Journal of Applied Earth Observation and Geoinformation, 4 (2), 147-160.

[22] Chen, Y., Huang, C., Ticehurst, C., Merrin, L., Thew, P. 2013. An evaluation of MODIS daily and 8-day composite products for floodplain and wetland inundation mapping. Wetlands, 33 (5), 823-835.

[23] Ticehurst, C., Guerschman, J.P., Chen, Y. 2014. The strengths and limitations in using the daily MODIS open water likelihood algorithm for identifying flood events. Remote Sensing, 6 (12), 11791-11809. 